\title{
ECONOMIC EVALUATION AND DESIGN \\ OF AN ELECTRIC ARC FURNACE CONTROLLER BASED ON ECONOMIC OBJECTIVES
}

\author{
by
}

\section{Daniël Jacobus Oosthuizen}

Submitted in partial fulfillment of the requirements for the degree

Master of Engineering (Electronic Engineering) in the

Faculty of Engineering, the Built Environment and Information Technology

UNIVERSITY OF PRETORIA

November 2001 
Economic evaluation and design of an electric arc furnace controller based on economic objectives

Daniël Jacobus Oosthuizen

Professor I.K. Craig

Professor P.C. Pistorius

Department of Electrical, Electronic and Computer Engineering

Master of Engineering (Electronic Engineering)

\begin{abstract}
The economic benefits of Model Predictive Control (MPC) over conventional manual control on an Electric Arc Furnace (EAF) are determined by means of a simulation study. The structure used for the MPC controller is chosen such that the objective function, which is minimised by the controller, corresponds to the cost of a tap. Minimisation of the objective function thus constitutes minimising EAF operational cost. The major factors contributing to the cost of the tap are thus determined and their contributions relative to each other quantified. The procedure of translating functional control objectives into economic objectives is discussed, as is the relative cost contribution of the feed additions to the EAF.
\end{abstract}

An existing EAF model is expanded by modelling the slag foam depth. The foam depth is useful in ensuring efficient energy transfer to the melt. Great emphasis is placed on ensuring that the simulation study is representative of operational conditions typically experienced in industry. Only continuous measurements are therefore used for continuous feedback, and measurements taken at discrete time intervals are only fed back at the time intervals indicated by plant data. The full non-linear model is used to simulate the plant, even though a linearised model is implemented as the internal plant model for the MPC controller. Disturbances are chosen based on plant data and suggestions from industry. 
The process of an experimental design for controller evaluation is discussed in detail. The selection of an appropriate experimental technique, possible threats to data integrity, tools for data analysis and capital budgeting tools form part of the complete experimental procedure. A framework is presented to ensure that useful data is generated and that valid conclusions are made concerning the data. This evaluation framework forms the basis of the experimental procedure used to compare the two control strategies (manual and MPC). The simulation study represents a test conducted over a period of one month, and randomisation is used to ensure that the test data is not correlated to the disturbances. Hypothesis testing is performed to ensure that the result is statistically significant.

Simulation results indicate large potential benefits attributable to MPC control. Improved utilisation of feed materials can potentially reduce the cost per ton of steel by $0.8 \%$. The major portion of the potential benefits is however due to the elimination of unscheduled delays, by ensuring that steel specifications are met at tapping, and that off-gas limits are not exceeded at any stage during the tap. These factors account for potential savings in excess of $7 \%$ due to increased throughput.

Keywords: Electric Arc Furnace, Model Predictive Control, Economic evaluation, Experimental design, Hypothesis testing, Dynamic models. 
Economic evaluation and design of an electric arc furnace controller based on economic objectives

Daniël Jacobus Oosthuizen

Professor I.K. Craig

Professor P.C. Pistorius

Departement Elektriese, Elektroniese en Rekenaar Ingenieurswese Magister in Ingenieurswese (Elektroniese Ingenieurswese)

\section{OPSOMMING}

Die finansiële voordele van 'n Model Voorspellende Beheerder is in 'n simulasie-studie bepaal, deur dit te vergelyk met konvensionele hand-beheer op 'n elektriese boogoond. Die struktuur van die beheerder is sodanig gekies, dat die doelwit-funksie wat deur die beheerder geminimeer word ooreenkom met die koste van 'n tap. Minimering van die doelwit-funksie is dus ekwivalent daaraan om die bedryfskoste van die boogoond te minimeer. Die belangrikste faktore wat bydra tot die koste van ' $n$ tap is daarom geïdentifiseer en die relatiewe bydraes tot die totale koste gekwantifiseer. Die omskrywing van funksionele doelwitte in terme van finansiële doelwitte is bespreek en die relatiewe kostes van die toevoer-materiale bepaal.

'n Bestaande boogoond model is uitgebrei deur die skuimslakdiepte te modelleer. Die skuimslakdiepte is van belang, aangesien effektiewe energie-oordrag na die bad hierdeur beïnvloed word. Klem is daarop gelê dat die simulasie-studie verteenwoordigend moet wees van omstandigdhede wat tipies in die industrie aangetref word. Slegs metings wat kontinu beskikbaar is word daarom kontinu teruggevoer. Metings wat slegs op diskrete tydstippe beskikbaar is word slegs teruggevoer op dié tydstippe aangedui in aanlegdata. Die volledige nie-lineêre model is gebruik om die aanleg te simuleer, al is 'n lineêre model gebruik as die interne aanleg-model vir die Model Voorspellende Beheerder. Steurings is gebaseer op aanlegdata en voorstelle deur aanleg personeel.

Eksperimentele ontwerp met die doel om beheerders te evalueer is in detail bespreek. Die keuse van 'n geskikte eksperimentele tegniek, potensiële bedreigings vir data integriteit, prosedures vir data analise en projek-evaluerings tegnieke maak deel uit van die eksperimentele prosedure. 
'n Raamwerk is voorgestel waarbinne verseker kan word dat bruikbare data gegenereer sal word en dat geldige gevolgtrekkings gemaak kan word oor die data. Hierdie evalueringsraamwerk vorm die basis van die eksperimentele prosedure wat gebruik is om die twee beheerstrategieë te vergelyk (Model Voorspellende Beheer en hand-beheer). 'n Toets uitgevoer oor die bestek van een maand word deur die simulasiestudie voorgestel. Ewekansige tegnieke is gebruik om te verseker dat geen korrelasie tussen die data en die steurings bestaan nie. Hipotese toetsing is gebruik om te bepaal of die resultate statisties beduidend is.

Die simulasiestudie dui op groot potensiële finansiële voordele weens Model Voorspellende Beheer. Beter benutting van toevoer-materiale kan die koste per ton staal potensieel verminder met $0.8 \%$. Die grootste deel van die potensiële besparing is egter vanweë die eliminasie van ongeskeduleerde onderbrekings. Dit word bewerkstellig deur te verseker dat aan staal temperatuur en -samestelling spesifikasies voldoen word wanneer getap word en dat die afgas temperatuur nie gespesifiseerde limiete oorskry nie. Hierdie faktore kan potensieel lei tot addisionele besparings van groter as $7 \%$ danksy verhoogte deurset.

Sleutelterme: Elektriese boogoond, Model Voorspellende Beheer, Ekonomiese evaluering, Eksperimentele ontwerp, Hipotese toetsing, Dinamiese modelle. 


\section{ACKNOWLEDGEMENTS}

I which to thank Prof. I.K. Craig and Prof. P.C. Pistorius for their meaningful guidance in the course of this dissertation. I would also like to thank Mintek for their financial support.

Information regarding typical operational practices on Electric Arc Furnaces (EAFs) was obtained from Iscor and Corus steel, U.K. I which to thank Mr. Philip Schutte and his colleagues at Iscor in particular, for their willingness to discuss sensitive information and to answer endless questionnaires within a limited time span. I also which to thank Mr. Andrew Chown and his colleagues at Corus steel for their willingness to discuss their furnace practices at short notice. The information obtained during these two interviews provided useful insight into aspects typically not considered during purely theoretical analyses.

I which to thank everyone involved in proof reading and formatting this dissertation. Your contribution is appreciated.

I would like to thank my wife, Tina, for her motivation and support during the dissertation. Finally, I which to thank the Lord for giving me the determination and the ability to complete this dissertation. 


\section{TABLE OF CONTENTS.}

Chapter 1: Introduction.

1.1. Motivation.

1.2. Background.

1.3. Problem statement. 3

1.4. Contribution. 3

1.5. Dissertation approach. 4

1.6. Organisation.

Chapter 2: Process Overview. $\quad 7$

$\begin{array}{ll}\text { 2.1. Introduction. } & 7\end{array}$

2.2. Process Description.

2.3. Simulation model. 11

2.4. Control objectives. 13

2.5. Modelling of slag foaming. 19

$\begin{array}{ll}\text { 2.6. Conclusion. } & 21\end{array}$

Chapter 3: The cost of EAF operation. 22

3.1. Introduction. 22

3.2. Background. 22

3.3. Cost components of EAF operation. 23

3.3.1. Operational cost considerations. 23

3.3.2. Cost implication of controlled variables. 26

3.3.2.1. Percentage carbon in the steel melt. 27

3.3.2.2. Steel temperature. 28

$\begin{array}{ll}3.3 .2 .3 \text {. Steel mass. } & 30\end{array}$

3.3.2.4. CO emission. 31

3.3.2.5. Relative furnace pressure. 31

3.3.2.6. Off-gas temperature. 33

3.3.2.7. Slag foam depth. 34

3.4. Conclusion. 36 
Chapter 4: Model Predictive Control.

4.1. Introduction. 37

4.2. Background. 38

4.3. Design strategy. 41

4.4. Conclusion. 44

Chapter 5: Controller design. $\quad 45$

5.1. Introduction. 45

5.2. Plant linearisation. 45

5.2.1. Model transformation. 45

5.2.2. Linear model derivation. 47

5.2.3. Comparison of linear and non-linear plant models. 50

5.3. Open loop system analysis. 55

5.4. Design procedure. 56

5.4.2. Control and prediction horizons. 56

5.4.3. Constraints on manipulated variables. 57

5.4.4. Constraints on controlled variables. 57

5.4.5. Weights. 59

5.4.5. Setpoints. 63

5.4.6. Additional tuning. 65

5.5. Closed loop system analysis. 66

5.5.1. Stability. 67

5.5.2. Frequency domain analysis. $\quad 67$

5.5.3. Sampling interval verification. 72

5.6. Controller implementation. 73

$\begin{array}{ll}\text { 5.7. Conclusion. } & 79\end{array}$ 
Chapter 6: The evaluation of control systems.

$\begin{array}{ll}\text { 6.1. Introduction. } & 80\end{array}$

6.2. Experimental techniques for comparative experiments. 80

6.3. Statistical tools. 84

6.4. The duration of an experiment. $\quad 87$

6.5. Threats to validity. 88

6.6. An evaluation framework. $\quad 89$

6.7. The economic evaluation of controllers. 92

$\begin{array}{ll}\text { 6.8. Conclusion. } & 97\end{array}$

$\begin{array}{ll}\text { Chapter 7. Simulation Study. } & 98\end{array}$

$\begin{array}{ll}\text { 7.1. Introduction. } & 98\end{array}$

7.2. Modelling of feed variations. 99

$\begin{array}{ll}\text { 7.3. Evaluation strategy. } & 100\end{array}$

7.3.1. Process understanding. $\quad 100$

7.3.2. Define the problem to be solved. 101

7.3.3. Determine the variables to be measured. 101

7.3.4. Determine the accuracy of the measurements and calibrate instrumentation. 102

7.3.5. Determine the distribution of a derived variable by examining the $\begin{array}{ll}\text { propagation of error through the system. } & 102\end{array}$

7.3.6. Make a list of factors influencing the value of the response variable, which could invalidate the result. 103

$\begin{array}{ll}\text { 7.3.7. Threats to validity. } & 104\end{array}$

$\begin{array}{ll}\text { 7.3.7.1. Internal validity. } & 104\end{array}$

7.3.7.2. External validity. 105

7.3.7.3. Statistical conclusion validity. 105

7.3.7.4. Conduct conclusion validity. 106

7.3.8. State the hypothesis that needs to be tested. 106

7.3.9. Design an experiment to generate unbiased production data. 107

7.3.10. Monitor the experiment and make sure it is carried out as planned. $\quad 108$

7.3.11. Analyse the generated data and determine sample statistics for each. $\quad 108$

7.3.12. Test and accept or reject the hypothesis. $\quad 110$

7.3.13. Estimate the monetary benefits. 113

7.3.14. Do an economic project evaluation. 114 
7.4. Discussion.

7.5. Conclusion.

Chapter 8: Conclusions and Recommendations.

8.1. Summary of dissertation contents.

8.2. Conclusions.

8.3. Recommendations. 